\title{
Optimalisasi Pelaksanaan Metode SBAR dalam Meningkatkan Komunikasi Efektif Di Ruang P RS X Jakarta
}

\author{
Indri Sarwili ${ }^{1}$, Rina Afrina ${ }^{2}$, Bambang Suryadi ${ }^{3}$ \\ Departement : Jl.Harapan $50 \mathrm{Gd}$.HZ Lenteng Agung (STIKes Indonesia Maju, Departemen \\ Keperawatan, Indonesia) \\ Email : indrisarwili@gmail.com
}

\begin{tabular}{|c|c|}
\hline Artikel Info & Abstrak \\
\hline $\begin{array}{l}\text { Ciptaan disebarluaskan di } \\
\text { bawah Lisensi Creative } \\
\text { Commons Atribusi- } \\
\text { BerbagiSerupa } 4.0 \\
\text { Internasional. }\end{array}$ & $\begin{array}{l}\text { Latar Belakang: Hasil pengkajian mengidentifikasi adanya kendala dalam } \\
\text { pelaksanaan metode SBAR dalam komunikasi ri ruang rawat inap } \\
\text { sehingga berdampak pada penurunan pelayana keperawatan. Tujuan: } \\
\text { penelitian ini bertujuan untuk mengidentifikasi akar penyebab masalah } \\
\text { yang ditemukan dan menemukan inovasi sebagai landasan perubahan } \\
\text { dalam area rumah sakit. Metode: Penulis menggunakan metode studi }\end{array}$ \\
\hline $\begin{array}{l}\text { Kata Kunci : SBAR,timbang } \\
\text { terima, perawat }\end{array}$ & $\begin{array}{l}\text { kasus. Hasil: Pelaksanaan komunikasi SBAR belum menjadi budaya } \\
\text { dalam keseharian komunikasi intern perawat ataupun tatalaksana antar } \\
\text { perawat dan professional pemberi asuhan lain. Kesimpulan: sosialisasi } \\
\text { pelaksanaan komunikasi metode SBAR serta penyampaian hal yang } \\
\text { penting yang harus ditindak lanjuti oleh perawat berikutnya dalam } \\
\text { komunikasi efektif dapat mengoptimalkan implementasi asuhan } \\
\text { keperawatan. }\end{array}$ \\
\hline
\end{tabular}

\section{Pendahuluan}

Kesehatan di era globalisasi seperti sekarang ini menjadi masalah yang paling dicermati oleh masyarakat pada umumnya, kemajuan suatu negara berkembang harus didasari dengan peningkatan derajat kesehatan. Semakin tinggi tingkat kesehatan yang ada disuatu negara maka pengeluaran negara untuk kesehatan masyarakat akan berkurang dan alokasi dananya bisa untuk membangun infrastruktur serta mensejahterakan masyarakatnya. Kesehatan merupakan kondisi kesejahteraan fisik, mental, dan sosial yang lengkap dan bukan sekedar tidak adanya penyakit atau kelemahan.1 Pemahaman tentang kesehatan telah bergeser seiring jalannya waktu. Makna kesehatan telah berkembang seiring dengan waktu, dalam perspektif model biomedis kesehatan di fokuskan pada kemampuan tubuh untuk berfungsi. Kesehatan dipandang sebagai kondisi tubuh yang berfungsi normal yang dapat terganggu oleh penyakit dari waktu ke waktu. ${ }^{1}$ kesehatan sekarang menjadi amat penting yang diperhatikan untuk mencapai derajat hidup yang optimal.

Rumah sakit merupakan tempat atau bagian yang paling dikunjungi bila seseorang merasa sakit, pelayanan yang paripurna dari suatu rumah sakit dapat memberikan kepuasan kepada masyarakat. Rumah sakit yang paripurna adalah rumah sakit yang dapat memberikan pelayanan kesehatan dan asuhan keperawatan yang terbaik untuk kesembuhan lebih cepat pasien pada suatu penyakit dengan tetap memperlihatkan keselamatan pasien (pasien safety). Rumah sakit adalah bagian internal dari suatu organisasi sosial dan kesehatan dengan fungsi menyediakan pelayanan paripurna (komprehensif), penyembuhan penyakit (kuratif) dan pencegahan penyakit (preventif) kepada masyarakat . ${ }^{2}$ Rumah sakit merupakan organisasi yang sangat kompleks dan sangat penting dalam upaya peningkatan derajat kesehatan masyarakat 
Indonesia. Rumah sakit sebagai salah satu penyelenggara pelayanan kesehatan, salah satunya adalah penyelenggara pelayanan asuhan keperawatan senantiasa memberikan pelayanan yang memuaskan kepada klien maupun keluarganya (Depkes, 2010). ${ }^{3}$ Oleh karena itu, diperlukan cara pengelolaan pelayanan keperawatan yang mengikuti prinsip-prinsip manajemen. Rumah sakit didirikan mempunyai tujuan mempermudah akses masyarakat untuk mendapatkan pelayanan kesehatan, memberikan perlindungan terhadap keselamatan pasien, masyarakat, lingkungan rumah sakit dan sumber daya manusia di rumah sakit, meningkatkan mutu dan mempertahankan standar pelayanan rumah sakit, memberikan kepastian hukum kepada pasien, masyarakat, sumber daya manusia rumah sakit dan rumah sakit (UU No.4 Kesehatan, 2009). ${ }^{4}$ Keberadaan rumah sakit sebagai suatu lembaga yang menyediakan pelayanan jasa kesehatan sering kali menimbulkan tekanan psikologis dan ekonomi bagi konsumennya. Selama ini masyarakat awam lebih mengenal rumah sakit sebagai tempat mengobati dengan bayangan perlakuan medis yang akan diterima melalui peralatan kedokteran. Kebutuhan masyarakat akan pelayanan kesehatan akhir - akhir ini meningkat hingga mencapai angka 85\%.

Ditambah dengan fenomena sekarang yang menunjukkan adanya kecenderungan konsumen yang lebih memilih untuk berobat ke luar negeri, yang memang harus diakui fasilitas dan layanannya jauh lebih baik dari yang dimiliki di dalam negeri. Sebuah rumah sakit yang baik tentunya mengutamakan mutu dan kualitas dari pelayanan pada konsumen. Namun disamping itu, bentuk fisik dan interior juga berperan menentukan baik buruknya penilaian konsumen terhadap rumah sakit tersebut. Setidaknya dengan bentuk fisik dan interior dari bangunan rumah sakit yang baik akan dapat mengurangi kesan menyeramkan sehingga mempercepat proses penyembuhan.

Keperawatan adalah suatu bentuk pelayanan profesional yang merupakanbagian integral dari pelayanan kesehatan, didasarkan pada ilmu keperawatan. Pelayanan tersebut berupa pelayanan yang komprehensif, bio-psiko-sosio-spiritualditujukan kepada perorangan, keluarga dan masyarakat dan mencangkup seluruh proses kehidupan manusia $(\mathrm{WHO}, 2010) .{ }^{5}$ Keperawatan adalah kegiatan pemberian asuhan kepada individu, keluarga, kelompok, atau masyarakat, baik dalam keadaan sakit maupun sehat. Perawat adalah seseorang yang telah lulus pendidikan tinggi keperawatan, baik di dalam maupun luar negeri yang diakui oleh pemerintah sesuai dengan ketentuan Peraturan Perundang-undangan. Pelayanan keperawatan adalah suatu bentuk pelayanan profesional yang merupakan bagian integral dari pelayanan kesehatan yang di dasarkan pada ilmu dan kiat keperawatan ditujukan kepada individu, keluarga, kelompok, atau masyarakat, baik sehat maupun sakit (UU Keperawatan No.38, 2014). Manajemen Keperawatan adalah suatu ilmu yang harus dimiliki oleh perawat untuk dapat mempunyai peran sebagai dalam merencanakan tindakan yang akan dilakukan untuk pasien sesuai dengan keluhan yang didapat saat melakukan pengkajian, mampu mengorganisasikan perawat yang dimiliki, sarana dan prasarana yang memadai untuk dapat melakukan asuhan keperawatan terbaik, mampu mengarahkan apa yang ingin dikerjakan sesuai dengan perencanaan yang telah dibuat, serta mampu mengawasi setiap pelaksanaan asuhan keperawatan yang telah dilakukan sesuai dengan SPO yang telah dibuat.

Manajemen keperawatan merupakan suatu proses menyelesaikan suatu pekerjaan melalui perencanaan, pengorganisasian, pengarahan, dan pengawasan dengan menggunakan sumber daya secara efektif, efisien dan rasional dalam memberikan pelayanan bio-psiko-sosial-spiritual yang komprehensif pada individu, keluarga, dan masyarakat, baik yang sakit maupun yang sehat melalui proses keperawatan untuk mencapai tujuan yang telah ditetapkan (Asmuji, 2014). ${ }^{6}$ Manajemen keperawatan merupakan pelaksanaan pelayanan keperawatan melalui staf keperawatan 
untuk memberikan asuhan keperawatan kepada pasien. Manajemen mengandung tiga prinsip pokok yang menjadi ciri utama penerapannya yaitu efisiensi dalam pemanfaatan sumber daya, efektif dalam memilih alternatif kegiatan untuk mencapai tujuan organisasi, dan rasional dalam pengambilan keputusan manajerial. Penerapan manajemen keperawatan memerlukan peran tiap orang yang terlibat di dalamnya untuk menyikapi posisi masing-masing melalui fungsi manajemen (Muninjaya, 2004). ${ }^{7}$ Fungsi manajemen akan mengarahkan perawat dalam mencapai sasaran yang akan ditujunya. Menurut Freeman dan Gilbert (1996) dalam Schlosser (2003) terdapat beberapa elemen utama dalam fungsi manajemen keperawatan diantaranya yaitu planning, organizing, actuating (coordinating \& directing), staffing, leading, reporting, controling dan budgeting. Komunikasi merupakan bagian dari strategi coordinationg (koordinasi) yang berlaku dalam pengaturan pelayanan keperawatan. Menurut Swansburg (2000),8 komunikasi dalam praktik keperawatan profesional merupakan unsur utama bagi perawat dalam melaksanakan asuhan keperawatan dalam mencapai hasil yang optimal sehingga peran komunikasi sangat penting dalam penerapan manajemen keperawatan. Adapun salah satu komunikasi yang dilakukan perawat secara rutin yaitu kegiatan timbang terima pasien saat pertukaran shift keperawatan yang juga merupakan salah satu dari enam sasaran keselamatan pasien.

Manajemen keperawatan merupakan suatu proses bekerja melalui anggota staf keperawatan untuk memberikan asuhan keperawatan secara profesional. (Gillies,2006). ${ }^{9}$ Manajemen keperawatan merupakan pelayanan keperawatan profesional dimana tim keperawatan dikelola dengan menjalankan empat fungsi manajemen, yaitu perencanaan, pengorganisasian, motivasi dan pengendalian. Keempat fungsi tersebut saling terkait serta saling berhubungan dan memerlukan keterampilan-keterampilan teknis, hubungan antar manusia dan konseptual yang mendukung tercapainya asuhan keperawatan yang bermutu, berdaya guna dan berhasil guna kepada klien. Dengan alasan tersebut manajemen keperawatan perlu mendapat perhatian dan prioritas utama dalam pengembangan keperawatan di masa depan. Hal tersebut berkaitan dengan tuntutan profesi dan tuntutan global bahwa setiap perkembangan dan perubahan memerlukan pengelolaan secara profesional dengan memperhatikan setiap perubahan yang terjadi. (Nursalam, 2014). ${ }^{10}$ Timbang terima shift jaga perawat masuk kedalam proses asuhan keperawatan, dimana proses timbang terima ini menitikberatkan pada komunikasi efektif yang diberikan saat melakukan timbang terima. Timbang terima merupakan sebuah pelimpahan wewenang serta tanggung jawab utama dalam memberikan perawatan kepada pasien antar shift jaga di Rumah Sakit. Kegiatan dalam timbang terima adalah menyampaikan laporan kondisi pasien berdasar asuhan keperawatan yang telah dilaksanakan perawat selama jam dinasnya.

RS X Jakarta merupakan Rumah Sakit yang berada ditengah-tengah kota Jakarta. RS X Jakarta memiliki tujuan untuk menyelenggarakan dukungan kesehatan dan pelayanan kesehatan terpadu yang bermutu dengan mengutamakan keselamatan pasien, melaksanakan pendidikan dan penelitian, Melaksanakan kegiatan pengabdian kepada masyarakat, Mengembangkan manajemen sumber daya manusia dan penataan kelembagaan rumah sakit yang berorientasi pada mutu. Ruang $P$ lantai 4 terdiri dari ruang perawatan Bedah, perawatan penyakit dalam, perawatan neurologi dan ruang Perawatan Anak dengan total 20 Bed. Dalam pengelolaan asuhan keperawatan profesionalnya merupakan model pemberian asuhan keperawatan dengan metode TIM, 
melalui kerja kelompok yang terkoordinasi dan kooperatif dapat terwujud pemberian asuhan keperawatan yang menyeluruh lengkap terhadap pasien. Keperawatan merupakan komponen penting didalam suatu Rumah Sakit, dimana keperawatan merupakan salah satu bagian ujung tombak dari suatu Rumah Sakit dalam memberikan pelayanan kesehatan yang paripurna. Keberhasilan suatu Rumah Sakit dalam memberikan pelayanan terbaik tidak lepas dari bagian keperawatan dalam memberikan asuhan keperawatan yang komprehensif dan berkesinambungan, karena keperawatan bekerja 24 jam sehari untuk memantau keadaan pasien.

\section{Metode}

Studi kasus dilakukan untuk menganalisis pelaksanaan timbang terima di RS X. Pengumpulan data dilakukan dengan menelaah dokumen, wawancara, dan kuesioner yang disebarkan kepada tenaga keperawatan yang telah bekerja lebih dari tiga tahun di ruangan P RS $X$ Jakarta, dan kepada kepala ruangan juga ketua tim yang bekerja di ruangan tersebut. Analisis situasi dilakukan dengan analisis tulang ikan/fish bone dengan tujuan mengidentifikasi factorfaktor penyebab ketidakoptimalan pelaksanaan timbang terima, kemudian dibuat rencana tindakan bersama dengan kepala ruangan, ketua tim dan perawat pelaksana berdasarkan permasalahan yang ada. Analisis didasarkan pada peran dan fungsi manajemen keperawatan.

\section{Hasil}

Hasil studi kasus menunjukkan bahwa fasilitas ruang perawatan $\mathrm{P}$ mempunyai kapasitas 17 tempat tidur untuk ruang perawatan kelas 1 , ruang perawatan kelas 2 serta ruang perawatan kelas 3 . Ruang rawat inap $P$ merupakan ruang perawatan yang digunakan untuk perawatan bedah yang berada di sisi bagian kanan, serta untuk perawatan penyakit dalam, neurologi dan penyakit lainnya yang berada di sisi bagian kiri. Ruang perawatan untuk kelas 3 terdiri dari 9 bed, untuk kelas 2 terdiri dari 6 bed, untuk kelas 1 terdiri dari 6 bed, serta 3 bed untuk intermediet. Struktur Organisasi Ruangan P di RS X Jakarta adalah sebagai berikut:

Bagan 1. Organisasi Ruangan

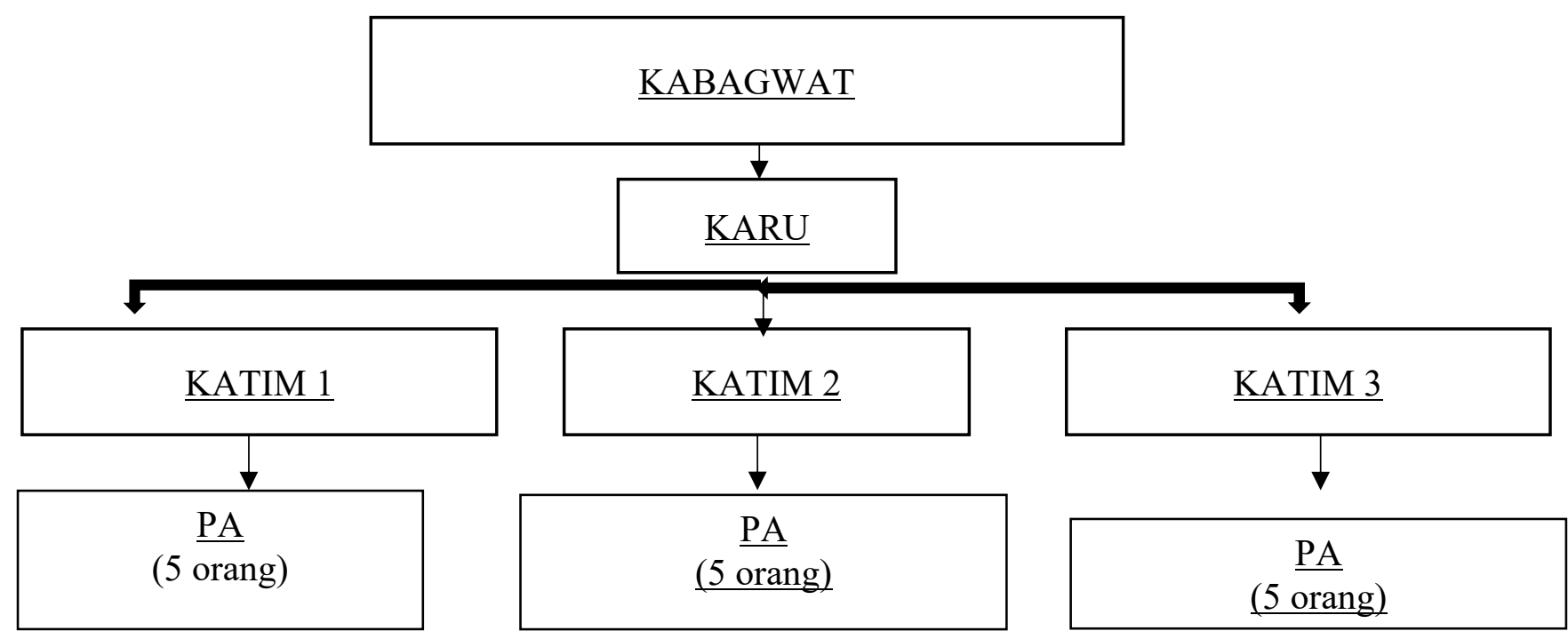


Ketenagaan Ruangan terdiri dari ketua tim dengan Pendidikan terakhir D3 dan masa kerja >25 tahun berjumlah tiga orang, dan perawat pelaksana dengan Pendidikan terakhir D3 keperawatan berjumlah lima orang yang dibagi menjadi tiga tim. Salah satu masalah yang ditemukan adalah kurang optimalnya komunikasi yang efektif, terutama dalam menggunakan metode Sbar dalam aktifitas pelaksanaan asuhan sehari-hari. Instrumen timbang terima perawat dengan pendekatan komunikasi efektif SBAR ruang rawat inap, dibutuhkan modifikasi untuk mempermudah pelaksanaan timbang terima dan menyesuaikan dengan standar akreditasi rumah sakit terbaru yang mengedepankan keselamatan pasien, berfokus pada mutu pelayanan keperawatan, serta mengintegrasikan perkembangan teknologi dan informasi. SBAR merupakan singkatan dari situation, background, assessment, recomendation, yaitu suatu tehnik atau cara yang dapat digunakan untuk memfasilitasi komunikasi yang efektif, cepat dan tepat. Penggunaan format SBAR akan membantu perawat fokus terhadap aspek penting yang akan diinformasikan kepada teman sejawat selama proses timbang terima sehingga menjadi lebih baik, efektif dan efisien. Untuk metode SBAR ini masih banyak perawat yang belum mengerti ataupun bila sudah mengerti tapi hanya sebatas lisan saja tanpa adanya suatu format yang baku untuk dilaksanakan.

Identifikasi masalah diilustrasikan dalam analisis fish bone di bawah ini:

Bagan 2. Analisis Tulang Ikan/Fish Bone Ruang S RS X Jakarta

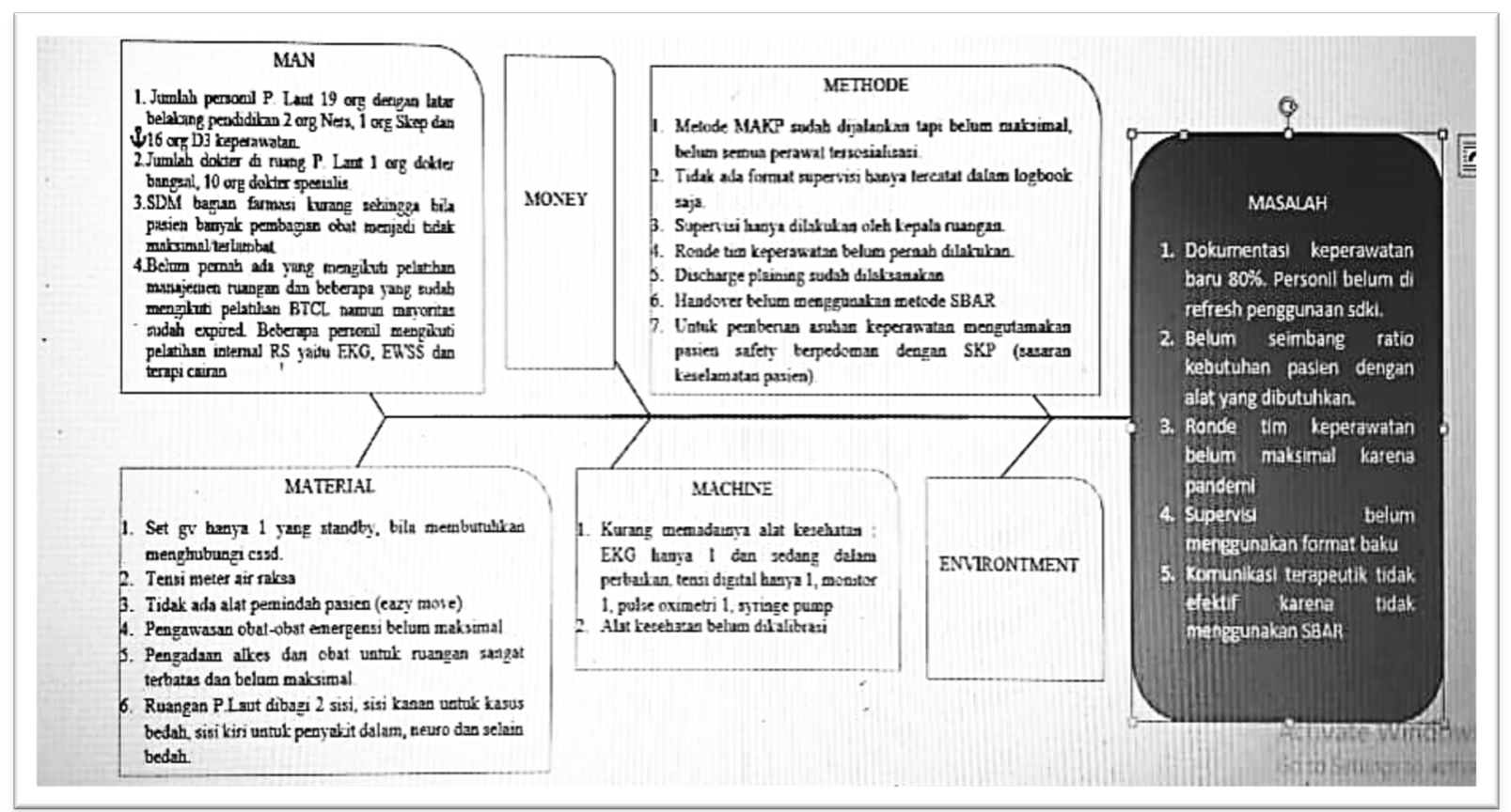

Permasalahan yang berhasil diidentifikasi, dipertimbangkan berdasarkan waktu, keterbatasan sumber daya, dan kewenangan atau kemampuan mengatasi masalah yang ada, sehingg a masalah yang akan diatasi adalah maslaah yang termasuk prioritas utama. Hasil identifikasi data di ruangan ditemukan beberapa masalah yang timbul, sehingga penulis membuat table prioritas masalah untuk menentukan masalah yang terlebih dahulu harus diselesaikan. Proses melakukan prioritas masalah dilakukan dengan mempehatikan aspek kecenderungan besar dan seringnya masalah tersebut, besarnya kerugian yang ditimbulkan dari masalah, bisa dipecahkan, melibatkan pertimbangan dan perhatian perawat, dan ketersediaan sumber daya. Masalah yang 
ditemukan tidak hanya terkait belum optimalnya model asuhan keperawatan profesioanl tim, tetapi masalah ini menjadi maslaah yang palong prioritas setelah dihitung menggunakan table prioritas masalah.

Tabel 2. Tabel Prioritas Masalah

\begin{tabular}{|c|l|c|c|c|c|c|c|}
\hline No. & \multicolumn{1}{|c|}{ Masalah } & $\begin{array}{c}\text { Mg } \\
\text { A }\end{array}$ & $\begin{array}{c}\text { Sv } \\
\text { b }\end{array}$ & $\begin{array}{c}\text { Mn } \\
\text { c }\end{array}$ & $\begin{array}{c}\text { Ne } \\
\text { d }\end{array}$ & $\begin{array}{c}\text { Af } \\
\text { e }\end{array}$ & $\begin{array}{c}\text { Skor } \\
\text { axbxcxdxe }\end{array}$ \\
\hline 1 & $\begin{array}{l}\text { Pendokumentasian } \\
\text { keperawatan kurang optimal } \\
\text { dilakukan baru 80\% }\end{array}$ & 5 & 4 & 5 & 5 & 2000 \\
\hline 2 & $\begin{array}{l}\text { Belum seimbang ratio } \\
\text { kebutuhan pasien dengan alat } \\
\text { yang dibutuhkan }\end{array}$ & 4 & 4 & 4 & 4 & 4 & 1024 \\
\hline 3 & $\begin{array}{l}\text { Ronde tim keperawatan belum } \\
\text { maksimal }\end{array}$ & 4 & 5 & 4 & 4 & 4 & 1280 \\
\hline 4 & $\begin{array}{l}\text { Supervisi belum menggunakan } \\
\text { format baku terapeutik tidak } \\
\text { Komunikasi tak } \\
\text { efektif karena } \\
\text { menggunakan SBAR }\end{array}$ & 5 & 4 & 5 & 4 & 4 & 1600 \\
\hline & & 5 & 5 & 5 & 5 & 3125 \\
\hline
\end{tabular}

Tabel 3. Alternatif Penyelesaian Masalah

Berdasarkan masalah Komunikasi terapeutik tidak efektif karena tidak menggunakan SBAR, disusun beberapa penyelesaian masalah yang akhirnya ditentukan alternatif penyelesaian masalah yang paling prioritas sebagai berikut:

\begin{tabular}{|c|l|c|c|c|c|c|}
\hline No & \multicolumn{1}{|c|}{ Kegiatan } & Ca & Ab & Rc & Ld & $\begin{array}{c}\text { Skor } \\
\text { axbxcxdxe }\end{array}$ \\
\hline 1 & $\begin{array}{l}\text { Perawat mengkomunikasikan keadaan } \\
\text { pasien dan menyampaikan informasi yang } \\
\text { penting }\end{array}$ & 4 & 4 & 4 & 4 & 256 \\
\hline 2 & $\begin{array}{l}\text { Menyampaikan keadaan dan kondisi } \\
\text { keadaan pasien (data fokus ) }\end{array}$ & 5 & 4 & 4 & 4 & 320 \\
\hline 3 & $\begin{array}{l}\text { Menyampaikan hal yang sudah dan belum } \\
\text { dilakukan dalam asuhan keperawatan } \\
\text { kepada pasien }\end{array}$ & 3 & 4 & 4 & 4 & 192 \\
\hline 4 & $\begin{array}{l}\text { Menyampaikan hal yang penting yang harus } \\
\text { ditindak lanjuti oleh perawat berikutnya }\end{array}$ & 5 & 5 & 4 & 4 & 400 \\
\hline 5. & $\begin{array}{l}\text { Menyusun rencana kerja untuk dinas yang } \\
\text { berikutnya }\end{array}$ & 4 & 3 & 3 & 4 & 144 \\
\hline
\end{tabular}

Hasil perhitungan table seleksi alternatif masalah yang menjadi prioritas adalah penyampaian hal yang penting yang harus ditindak lanjuti oleh perawat berikutnya dalam pelaksanaan komunikasi efektif menggunakan metode SBAR.

\section{Pembahasan}

Transfer informasi pada saat pergantian shift disebut dengan handover. Informasi terkait keadaan klien, kebutuhan klien, keadaan personal klien, sampai apada faktor sosial pasien. Dampak apabila tidak tidak dilaksanakan komunikasi SBAR pada saat handover maka terjadi peningkatan resiko insiden keselamatan pasien. Berdadarkan hasil analisa, implementasi di $P$ menggunakan metode observasi dan wawancara didapatkan bahwa metode handover yang saat 
ini di lakukan di $\mathrm{P}$ baru 30\% menggunakan komunikasi SBAR namun penerapannya belum maksimal. Banyak informasi yang belum terisi mengenai kondisi pasien terkini, perawat hanya mengkomunikasikan keadaan umum, seharusnya pada komponen ini dijelaskan juga kondisi klinik yang lain yang mendukung keadaan pasien seperti hasil pemeriksaan TTV, laboratorium. Berdasarkan hasil analisa kelompok di dapatkan masalah prioritas sebagai berikut :komunikasi terapeutik belum efektif tidak menggunakan SBAR, pendokumentasian keperawatan yang belum optimal baru $80 \%$, supervisi belum mempunyai format baku, ronde tim keperawatan tidak ada serta belum seimbang ratio kebutuhan pasien dengan ketersediaan alat. Berdasarkan hasil tersebut maka pada tanggal 02 Juli 2021 telah dilakukan implementasi cara yang benar komunikasi terapeutik menggunakan SBAR, pedampingan mengecek kembali pendokumentasian keperawatan serta pembuatan format supervisi keperawatan.

Untuk masalah ronde tim keperawatan dan belum seimbangnya ratio kebutuhan pasien dengan ketersediaan alat kita delegasikan ke ruangan untuk menyelesaikan dengan POA. Timbang terima shift jaga perawat masuk kedalam proses asuhan keperawatan, dimana proses timbang terima ini menitikberatkan pada komunikasi efektif yang diberikan saat melakukan timbang terima. Timbang terima merupakan sebuah pelimpahan wewenang serta tanggung jawab utama dalam memberikan perawatan kepada pasien antar shift jaga di Rumah Sakit. Kegiatan dalam timbang terima adalah menyampaikan laporan kondisi pasien berdasar asuhan keperawatan yang telah dilaksanakan perawat selama jam dinasnya. Manajemen adalah suatu proses yang khas yang terdiri atas tindakan-tindakan perencanaan, pengorganisasian, pengarahan dan pengendalian yang dilakukan untuk menentukan serta mencapai sasaran yang telah ditentukan melalui pemanfaatan sumber daya manusia dan sumber-sumber lainnya ( $R$. Supomo dan Eti Nurhayati, 2018). ${ }^{11}$ Manajemen merupakan suatu pendekatan yang dinamis dan proaktif dalam menjalankan suatu kegiatan dalam suatu organisasi dimana dalam manajemen tersebut mencangkup kegiatan koordinasi dan

supervisi terhadap staf, sarana dan prasarana dalam mencapai tujuan organisasi (Nursalam, 2014). Manajemen adalah suatu proses yang khas yang terdiri atas tindakantindakan perencanaan, pengorganisasian, pengarahan dan pengendalian yang dilakukan untuk menentukan serta mencapai sasaran yang telah ditentukan melalui pemanfaatan sumber daya manusia dan sumber-sumber lainnya (R. Supomo dan Eti Nurhayati, 2018). Manajemen merupakan suatu pendekatan yang dinamis dan proaktif dalam menjalankan suatu kegiatandalam suatu organisasi dimana dalam manajemen tersebut mencangkup kegiatan koordinasi dan supervisi terhadap staf, sarana dan prasarana dalam mencapai tujuan organisasi (Nursalam, 2014). Selain itu, pelayanan keperawatan merupakan faktor penentu baik buruknya mutu dan citra dari rumah sakit, oleh karena itu kualitas pelayanan keperawatan perlu dipertahankan dan ditingkatkan hingga tercapai hasil yang optimal. Dengan memperhatikan hal tersebut, proses manajemen yang baik perlu diterapkan dalam memberikan asuhan keperawatan sehingga dicapai suatu asuhan keperawatan yang memenuhi standar profesi yang ditetapkan, sumber daya untuk pelayanan asuhan keperawatan dimanfaatkan secara wajar, efisien, efektif, aman bagi pasien dan tenaga keperawatan, memuaskan bagi pasien dan tenaga keperawatan serta aspek sosial, ekonomi, budaya, agama, etika, dan tata nilai masyarakat diperhatikan dan dihormati (Nursalam, 2014). Asuhan keperawatan adalah bentuk pelayanan kesehatan yang diberikan oleh seorang perawat untuk mengatasi masalah keperawatan pasien sesuai dengan keluhan yang di dapat saat pengkajian yang berkesinambungan dengan kiat-kiat keperawatan yang di mulai dari pengkajian sampai dengan evaluasi dalam usaha memperbaiki ataupun memelihara derajat kesehatan yang optimal. Asuhan keperawatan dalah seluruh rangkaian proses keperawatan yang diberikan kepada pasienAsuhan keperawatan amat sangat berperan penting dalam membantu proses penyembuhan pasien dengan disiplin ilmu keperawatan. Seorang perawat harus dapat melakukan asuhan keperawatan sesuai dengan SPO yang telah dibuat dan sesuai dengan kebijakan Rumah Sakit. 
Tabel 4. POA rencana program kerja

\begin{tabular}{|c|c|c|c|c|c|c|}
\hline Kegiatan & $\begin{array}{c}\text { Pokok } \\
\text { Kegiatan }\end{array}$ & Pelaksana & Sasaran & Tujuan & Waktu & Tempat \\
\hline \multirow[t]{3}{*}{$\begin{array}{l}\text { Pelaksanaan } \\
\text { komunikasi } \\
\text { efektif } \\
\text { menggunakan } \\
\text { metode SBAR }\end{array}$} & $\begin{array}{l}\text { Persiapan } \\
\text { Kolaborasi } \\
\text { dengan } \\
\text { Kepala } \\
\text { Ruangan atau } \\
\text { Kepala Tim } \\
\text { untuk } \\
\text { mengatur } \\
\text { jadwal } \\
\text { pertemuan } \\
\text { Menyiapkan } \\
\text { contoh SBAR }\end{array}$ & Mahasiswa & $\begin{array}{l}\text { Kepala } \\
\text { Ruangan } \\
\text { Kepala } \\
\text { Tim } \\
\text { Perawat } \\
\text { Pelaksana }\end{array}$ & $\begin{array}{l}\text { Mendiskusikan tentang } \\
\text { pentingnya komunikasi } \\
\text { efektif dengan } \\
\text { menggunakan metode } \\
\text { SBAR }\end{array}$ & $\begin{array}{l}\text { Jumat, } \\
\text { 02 Juli } \\
2021\end{array}$ & $\begin{array}{l}\text { Ruang } \\
\text { P }\end{array}$ \\
\hline & $\begin{array}{l}\text { Pelaksanaan } \\
\text { Mahasiswa } \\
\text { bersama } \\
\text { Kepala } \\
\text { Ruangan, } \\
\text { Kepala Tim } \\
\text { dan Perawat } \\
\text { Pelaksana } \\
\text { mengikuti Pre } \\
\text { Confrence dan } \\
\text { Post } \\
\text { Confrence } \\
\text { menggunakan } \\
\text { metode SBAR }\end{array}$ & Mahasiswa & $\begin{array}{l}\text { Kepala } \\
\text { Ruangan } \\
\text { Kepala } \\
\text { Tim } \\
\text { Perawat } \\
\text { Pelaksana }\end{array}$ & $\begin{array}{l}\text { Perawat } \\
\text { mengkomunikasikan } \\
\text { keadaan pasien dan } \\
\text { menyampaikan informasi } \\
\text { yang penting } \\
\text { Menyampaikan keadaan } \\
\text { dan kondisi keadaan } \\
\text { pasien ( data fokus ) } \\
\text { Menyampaikan hal yang } \\
\text { sudah dan belum } \\
\text { dilakukan dalam asuhan } \\
\text { keperawatan kepada } \\
\text { pasien } \\
\text { Menyampaikan hal yang } \\
\text { penting yang harus } \\
\text { ditindak lanjuti oleh } \\
\text { perawat berikutnya } \\
\text { Menyusun rencana kerja } \\
\text { untuk dinas yang } \\
\text { berikutnya }\end{array}$ & $\begin{array}{l}\text { Kamis, } \\
\text { 02 Juli } \\
2021\end{array}$ & $\begin{array}{l}\text { Ruang } \\
\text { P }\end{array}$ \\
\hline & $\begin{array}{l}\text { Evaluasi } \\
\text { Melakukan } \\
\text { monitoring } \\
\text { komunikasi } \\
\text { efektif dengan } \\
\text { menggunakan } \\
\text { metode SBAR }\end{array}$ & Mahasiswa & $\begin{array}{l}\text { Tenaga } \\
\text { perawat di } \\
\text { ruangan }\end{array}$ & $\begin{array}{l}\text { Mengetahui presentase } \\
\text { peningkatan pelaksanaan } \\
\text { komunikasi efektif dengan } \\
\text { metode SBAR }\end{array}$ & $\begin{array}{l}\text { Jumat, } \\
\text { 02 Juli } \\
2021\end{array}$ & $\begin{array}{l}\text { Ruang } \\
\text { P }\end{array}$ \\
\hline
\end{tabular}

\section{Kesimpulan}

Hasil pelaksanaan identifikasi data melalui obeservasi, wawancara yaitu komunikasi terapeutik belum efektif tidak menggunakan SBAR, dokumentasi keperawatan belum optimal baru $80 \%$, suepervisi belum menggunakan format baku, ronde tim keperawatan belum ada serta belum seimbang ratio kebutuhan pasien dengan alat yang dibutuhkan. Implementasi yang dilakukan yaitu melakukan pelaksanaan komunikasi efektif dengan menggunakan komunikasi 
SBAR meningkatkan pengetahuan, keterampilan, dan motivasi perawat pelaksana untuk menggunakan komunikasi SBAR dalam rangka peningkatan komunikasi efektif saat melaksanakan asuhan keperawatan terutama di ranah pelayanan Kesehatan di rumah sakit.

\section{Deklarasi Konflik Kepentingan}

menyatakan bahwa penelitian ini independen dari konflik kepentingan individu dan organisasi.

\section{Ucapan Terimakasih}

Terimakasih kepada tim stase keperawatan medikal bedah dan responden yang telah membantu proses penelitian ini

\section{Referensi}

1. Chao, Hsi-Chun, Hsiao-Wei Liao, and Ching-Hua Kuo. "Using water plug-assisted analyte focusing by micelle collapse in combination with microemulsion electrokinetic chromatography for analyzing phthalate esters." Journal of Chromatography A 1445 (2016): 149-157.

2. Busro, Achmad. "Aspek Hukum Persetujuan Tindakan Medis (Inform Consent) Dalam Pelayanan Kesehatan." Law, Development and Justice Review 1.1 (2018): 1-18.

3. Khamida, Khamida, and Mastiah Mastiah. "Kinerja Perawat Dalam Memberikan Asuhan Keperawatan Berpengaruh Terhadap Kepuasan Pasien Rawat Inap." Journal of Health Sciences 8.2 (2015).

4. Garin Tirana, N. P. M. TANGGUNG JAWAB RUMAH SAKIT HARAPAN BUNDA JAKARTA TIMUR TERHADAP PASIEN PENGGUNA VAKSIN PEDIACEL PALSU DITINJAU DARI UNDANGUNDANG NOMOR 44 TAHUN 2009 TENTANG RUMAH SAKIT JUNCTO UNDANG-UNDANG NOMOR 36 TAHUN 2009 TENTANG KESEHATAN. Diss. FAKULTAS HUKUM UNPAS, 2017.

5. JAENUDIN, Riswan. Peningkatan kualitas pendidikan melalui pendidikan budaya dan karakter bangsa. 2010.

6. Agustina, Nela. HUBUNGAN KOMPETENSI PERAWAT PELAKSANA DENGAN TINGKAT KEPUASAN PASIEN RAWAT INAP DI RUMAH SAKIT TINGKAT III BALADHIKA HUSADA JEMBER. Diss. Universitas Muhammadiyah Jember, 2018.

7. Muninjaya, AA Gde. "Manajemen kesehatan." EGC, 2004.

8. Suroso, Jebul. "Penataan sistem jenjang karir berdasar kompetensi untuk meningkatkan kepuasan kerja dan kinerja perawat di rumah sakit." Eksplanasi 6.2 (2012).

9. Anggeria, Elis, and Maria Maria. "Hubungan Supervisi dengan Pelaksanaan Asuhan Keperawatan di Ruang Rawat Inap Lantai 10 Rumah Sakit Umum Royal Prima Medan Tahun 2017." JUMANTIK (Jurnal Ilmiah Penelitian Kesehatan) 3.2 (2018): 78-97.

10. Nursalam, Dr. "Manajemen Keperawatan" Aplikasi dalam Praktik Keperawatan Profesional." (2014).

11. Pujiati, Eli, and $\mathrm{H}$. Dr Azhar Affandi. PENGARUH KOMPETENSI, BEBAN KERJA DAN KOMPENSASI TERHADAP KINERJA PERAWAT RUMAH SAKIT UMUM (RSU) AVISENA CIMAHI. Diss. Perpustakaan Fakultas Ekonomi dan Bisnis Unpas Bandung, 2018. 